\title{
The role of exercise and physical activity on aging-related diseases and geriatric syndromes
}

\section{El papel del ejercicio y la actividad física en las enfermedades relacionadas con el envejecimiento y los síndromes geriátricos}

\author{
Mehdi Kushkestani $^{1 *}$, Mohsen Parvani ${ }^{1}$, Mahmood Ghafari ${ }^{1}$, Zahra Avazpoor ${ }^{2}$ \\ ${ }^{1}$ Faculty of Physical Education and Sport Sciences, Allameh Tabataba'i University, Tehran, Iran \\ ${ }^{2}$ Faculty of Physical Education and Sport Sciences, Tehran University, Tehran, Iran \\ * Correspondence: Mehdi Kushkestani; mehdi.kushk@gmail.com
}

\begin{abstract}
Aging is a complex process of physiological and social changes that leads to various diseases. The number of elderly people in the world is increasing dramatically and it should be noted that rapid population aging represents a major public health burden. On the other hand, providing an appropriate and low-cost approach to control and prevent complications such as chronic diseases, physical dysfunction, and the geriatric syndrome is necessary. Also, numerous studies have shown that participation in physical activity and exercise training reduces the incidence of dysfunctional capacity, cardiovascular and metabolic disease, as well as the premature death rate in older adults. After plenty of precise observations about the role of exercise on aging-related diseases and geriatric syndromes articles, the benefits of exercise and physical activity in older adults will be more tangible. Therefore, the first purpose of the present review was to investigate the mechanisms of PA and exercises that are involved in the prevention of aging-related diseases and GS using current evidence (from 2015 onwards). Also, the purpose of this study was to provide an exercise guideline (aerobic and resistance training) based on recent evidence (from 2015 onwards).
\end{abstract}

\section{KEYWORDS}

Aging; Cardiovascular diseases; Exercise; Geriatric syndrome; Hypertension; Physical activity 


\section{RESUMEN}

El envejecimiento es un proceso complejo de cambios fisiológicos y sociales que conduce a diversas enfermedades. El número de personas de edad avanzada en el mundo está aumentando drásticamente y cabe señalar que el rápido envejecimiento de la población representa una importante carga para la salud pública. Por otro lado, es necesario brindar un enfoque adecuado y de bajo costo para controlar y prevenir complicaciones como enfermedades crónicas, disfunción física y síndrome geriátrico. Además, numerosos estudios han demostrado que la participación en la actividad física y el entrenamiento físico reduce la incidencia de disfunciones, enfermedades cardiovasculares y metabólicas, así como la tasa de muerte prematura en los adultos mayores. Después de muchas observaciones precisas sobre el papel del ejercicio en los artículos sobre enfermedades relacionadas con el envejecimiento y síndromes geriátricos, los beneficios del ejercicio y la actividad física en los adultos mayores serán más tangibles. Por lo tanto, el primer propósito de la presente revisión fue investigar los mecanismos de actividad física y ejercicios que están involucrados en la prevención de enfermedades relacionadas con el envejecimiento y síndrome geriátrico utilizando la evidencia actual (de 2015 en adelante). Además, el propósito de este estudio fue proporcionar una guía de ejercicio (entrenamiento aeróbico y de resistencia) basada en evidencia reciente (de 2015 en adelante).

\section{PALABRAS CLAVE}

Envejecimiento; Enfermedades cardiovasculares; Ejercicio; Síndrome geriátrico; Hipertensión; Actividad física

\section{INTRODUCTION}

Recently, social and economic changes, as well as the development of diverse sciences have greatly decreased age-related deaths which is the most important reason for an increase in the global elderly population (Kanasi et al., 2016). It has been predicted that the number of people over 60 will rise from 962 million in 2017 to 2.1 billion in 2050 (Nations, 2017). On the other word aging is a progressive loss of physical, mental, and cognitive integrity, leading to impaired functions and increased vulnerability to morbidity and mortality (A. Y. Chang et al., 2019). As described, aging is characterized by progressive degeneration of the tissues that have a negative impact on the structure and function of vital organs (Kushkestani et al., 2020). Loss of physiological integrity results in a progressive decline of homeostasis and reduced capacity of the body to respond to environmental stimuli with age and contributes to an incremental risk of disease and death (Davalli et al., 2016). In 
addition, aging is among the most important known risk factors in nearly all chronic diseases. Each day around 100000 people die from age-related causes worldwide (Harris, 2019).

Many pieces of evidence showed that increasing age is associated with many noncommunicable diseases (NCDs) such as cardiovascular disease (CVD), type 2 diabetes, cancer, osteoarthritis, metabolic syndrome (MetS) (Kushkestani, Parvani, Nosrani, \& Rezaei, 2020b; Lee \& Halter, 2017; Libby \& Kobold, 2019; Liguori et al., 2018). In addition, Geriatric syndromes (GSs) are clinical conditions identified more commonly in older adults, particularly in frail older adults (Magnuson et al., 2019); In fact, the GS is a set of conditions that occur together to lead to a particular disease or each of the symptoms alone causes a disorder in individuals (Cheung et al., 2018) During the aging process, the decline in the functional capacity of the body organs rendering individuals more susceptible to stressors. Thus, GS can be the result of the organs' dysfunction to control and compensate for stress factors (Cheung et al., 2018). Common GSs include Sarcopenia, falls, dementia, frailty, delirium, depression, polypharmacy, and urinary incontinence (Baijens et al., 2016). It has been well established that age-related physiological changes, such as alterations in cellular homeostasis mechanisms, decrease in body mass and function lead to various disorders and diseases as well as premature death in the elderly (Carmona \& Michan, 2016).

Recent evidence has shown that age-associated changes (risk factors) are divided into two groups: modifiable and unmodifiable. The unmodifiable factors are age and genetic, while modifiable factors are obesity, smoking, and physical inactivity. These changes are largely determined by genetics and are influenced by environmental factors such as exercise, diet, cigarette smoking, etc. (Kushkestani et al., 2020; Kuspinar et al., 2020). It has been well established that physical inactivity and sedentary behaviors in the elderly are leading public health concerns. They have been reported as the fourth prominent universal mortality-linked risk factor, an important contributing agent for physical dysfunctions and poor health consequences. The absence of enough physical activity (PA) is associated with nearly 3 million mortalities annually and to 6-10\% the incidence of significant chronic diseases (Gomes et al., 2017; Gopinath et al., 2018). In contrast, it has been reported that mild to high-intensity PA levels are related to a decreased risk of aging diseases, including Type 2 diabetes, CVDs, MetS, depression, and cancer (Gill, 2015). Da silva et.al (2019) reported that chronic PA and/or exercise training develop both psychological and physical health and contribute to the moderation of the disadvantaged effects of physical disabilities as well as the functional independence preservation in the elderly (da Silva et al., 2019). In addition, we have recently reported that PA and diet play an effective role in preventing, controlling and treating chronic diseases such as hypertension (Kushkestani et al., 2020; Pescatello et al., 2015), metabolic 
and CVD, age-related dysfunction (GS) the same as Sarcopenia, severe fatigue, fall, and improved quality of life (Kushkestani et al., 2020; Kushkestani, Parvani, \& maria Teixeira, 2020; Kushkestani, Parvani, Nosrani, \& Rezaei, 2020a; Nascimento et al., 2019; Tartibian et al., 2019), Decreasing neurodegeneration and cognitive dysfunction (Kushkestani et al., 2020, 2020), improving blood pressure, cardiac output (Hurst et al., 2019), endothelial and autonomic function, increasing $\mathrm{VO}_{2} \mathrm{max}$ and gas exchange, boosting metabolic function, immune function, modifying body composition, maintaining muscle and bone mass as well as muscle endurance and strength (Kushkestani et al., 2020; Liberman et al., 2017), improving balance, mobility and flexibility, are important effects of regular exercise and PA in aging (da Silveira Langoni et al., 2019; Kushkestani et al., 2020; Kushkestani, Parvani, \& Rezaei, 2020). Further, a considerable reverse relationship between cardiovascular mortality and occupational PA exists. Furthermore, many evidence has indicated this relation, with last meta-analyses that showed less risk for all fatality causes in subjects who exercise regularly.

As mentioned in previous sections, the general and physiological effects of exercise on the prevention, control, and treatment of age-related diseases and syndromes have been demonstrated in many studies. However, few studies in the field of aging and exercise have been conducted to examine the pathophysiological mechanisms of diseases and the preventive role of different types of exercise training. Therefore, the first purpose of the present review was to investigate the mechanisms of PA and exercises that are involved in the prevention of aging-related diseases and GS using current evidence (from 2015 onwards). Also, the late purpose of this study was to provide an exercise guideline (aerobic and resistance training) based on recent evidence (from 2015 onwards). Age-related risk factors, diseases, and syndromes have been studied in this paper, as shown in Figure 1. 


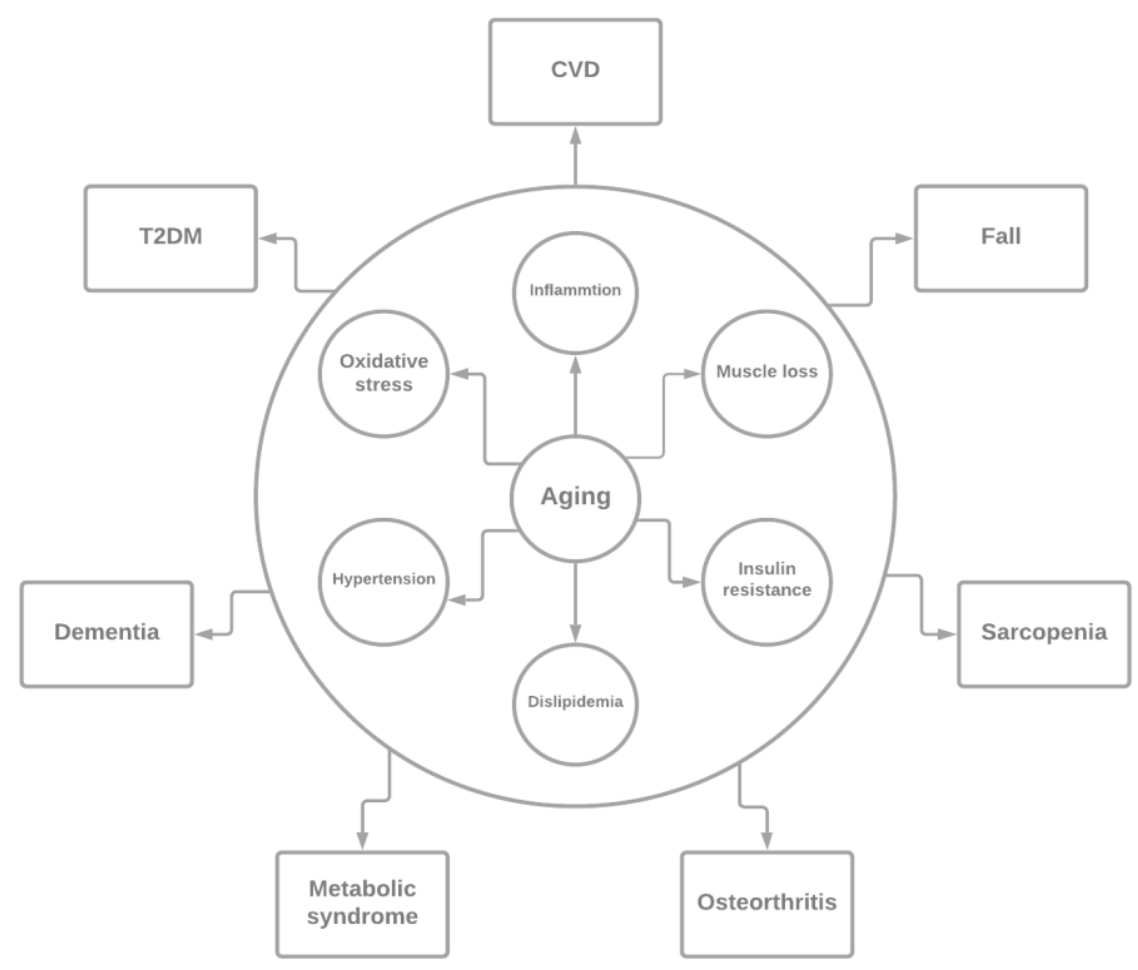

Figure 1: Age-related risk factors, diseases, and syndromes CVD: cardiovascular diseases, T2DM: type 2 diabetes mellitus

\section{METHODS}

\subsection{Data source and search}

We searched in three electronic databases: google scholar, PubMed/MEDLINE, EMBASE comprehensively. Keywords that were used in this study included "aging pathophysiology", "aging and non-communicable disease", "geriatric syndrome and exercise", and also exercise with "CVD, T2DM, hypertension, MetS, osteoarthritis, sarcopenia, fall and dementia" separately. We searched for any articles that were published after 2015 and in English. In addition, we manually sought whole references of elected papers for supplementary related studies. Also, no sex limitations were imposed throughout the search steps. Overall, we planned to carry out a review focusing on aging, related-GSs, and diseases, as well as endurance and resistance exercises.

\subsection{Inclusion and exclusion criteria}

In this study, we retained papers that met the following inclusion criteria: (1) be published in an electronic journal article, (2) epidemiological, original, and review studies about aging with NCDs and GSs and the pathophysiologic mechanisms of NCDs and GS in elderly, (3) and finally the 
effects of exercise on indices of mentioned diseases and syndromes in the elderly. Our exclusion criteria were: (1) Retracted papers, (2) articles that were published before 2015, in non-English and non-peer-review journals, (3) correspondence pieces, (4) case studies, (5) conference papers, (6) acute interventions studies.

\subsection{Data screen and extraction}

Two researchers screened titles, abstracts, and full-text papers independently and reported potentially qualified evidence. Data exploitation for all papers was duplicated via an independent researcher. 181 papers (original and review) were qualified according to our study inclusion and exclusion criteria. We divided all desirable evidence into the following four categories: (1) agingrelated NCDs and GSs (regarding the time), (2) chronic diseases and syndromes pathophysiology (regarding the age), (3) detrimental effects of physical inactivity in the elderly, and, (4) exercises (endurance and resistance) benefits in the prevention of NCDs (cellular and molecular mechanisms).

\section{RESULTS}

Experimental components of the papers are shown in figure 2. 1325 articles were initially identified from the databases. After removal of duplicates and exclusion of abstracts papers, conference papers, case studies, peer-reviewing, and acute-interventions studies, 181 papers were selected for this review. 506 articles were published before 2015, 358 articles were excluded after the titles review, 131 articles were excluded after the abstracts review, 24 articles were duplicates, 34 articles had an acute intervention, 84 articles were conference papers, and 7 articles were case studies. Besides following the above data screening and extraction, we excluded 22 other papers (5 articles had stretch training as interventions, 3 articles had complex exercise (intervention) training, and 14 articles had been measured new and non-established methods or incidences as markers of diseases). In addition, 48 articles were excluded following full-text review (they were no match with our study purpose) and finally 111 papers were selected in this narrative review. According to the purpose of this study, to write the discussion section, we used articles that thoroughly had examined the physiological mechanisms of regular physical activity and exercise in the prevention and treatment of aging-related diseases and GS. Further, in the discussion section, we considered papers that met the following inclusion criteria: (1) examined pathophysiologic mechanisms of diseases or syndromes, and (2) physiologic mechanisms of exercises (aerobic and resistance). According to our criteria, we selected 84 papers for the discussion section. In addition, regarding the effects of different interventions on various patients in the selected studies, we have prepared a table that show 
efficacy of different types of exercises in preventing, controlling, as well as treating of mentioned age-related diseases, table 2 .

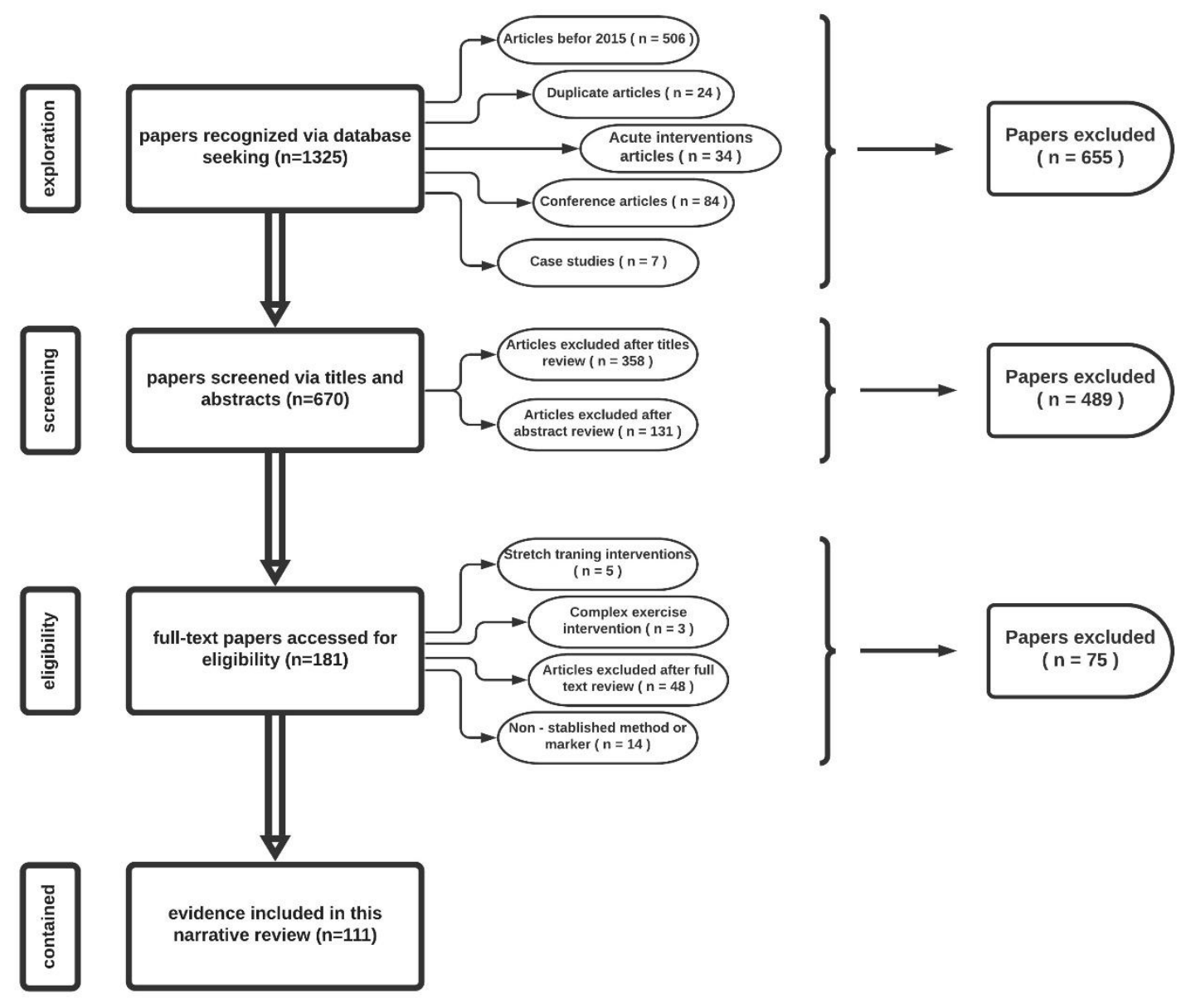

Figure 2. Steps of the article check and selection.

\section{DISCUSSION}

Regarding our criteria, the results of most of the selected articles in this review indicated the positive roles of physical activity and exercise in the treatment of syndromes and their associated risk factors in the elderly. Interestingly, in some of these studies, regular exercise was cited as the most crucial factor in successful aging. According to our division (in methods sections), we first generally investigated the common aging-related diseases and syndromes and their mortality separately. Then we presented the mechanism by which the preventive role of exercises in the controlling of aging consequences and also improving and treating their physiologic and pathophysiologic markers. Finally, we presented an exercise guideline concerning the elderly population. 


\subsection{Cardiovascular diseases}

Numerous reports indicate that CVDs are the leading cause of mortality in elderly people worldwide (Harris, 2019; Roth et al., 2017). There is ample evidence suggesting that increased levels of PA and exercise lead to improved cardiovascular fitness, thereby preventing, controlling, and ameliorating related diseases through various mechanisms (Altavilla et al., 2018; Barengo et al., 2017; Kushkestani et al., 2020). PA, especially moderate-to-high-intensity aerobic exercises such as walking, swimming, cycling, and running improves myocardial function and prevents CVD in elderly people by improving ejection fraction ratio (E/F), increased end-diastolic volume (EDV), cardiac output (CO), and diastolic function (Bouaziz et al., 2017; Recchioni et al., 2017). Also, the role of exercise in increased cardiac output in preventing CVD has been well proved and it is dependent on two physiological parameters of heart rate (HR) and stroke volume (SV). Increasing age results in a reduction in maximum $\mathrm{HR}, \mathrm{SV}$, and ultimately cardiac output by disrupting the cardiac autonomic nervous system (cANS) (Roh et al., 2016). In addition, exercise can increase cardiac output in the elderly by improving cardiac muscle function and SV (Pandey et al., 2017). On the other hand, maximal oxygen uptake (VO2max) has been identified as a strong indicator of cardiorespiratory fitness and a predictor of mortality caused by CVDs (Recchioni et al., 2017). In this regard, Jakovljevic et al. (2018) reported that level of total PA and exercise with appropriate intensity and volume lead to increased cardiac cell survival and play an effective role in the prevention and control of CVDs, including heart failure in the elderly people by reducing apoptotic and necrotic signaling pathways and improving mitochondrial function (Jakovljevic, 2018).

\subsection{Hypertension}

High blood pressure is one of the leading causes of CVD and mortality in the world (Arias et al., 2020). According to the Joint National Committee (JNC), more than two-thirds of older adults over the age of 65 have high blood pressure; hence, it is commonly believed that hypertension is an aging disorder that highlights the importance of controlling blood pressure in the elderly (Sun, 2015). With advancing age, the walls of large arteries become thicker and lose their elasticity over time. This process leads to an increase in pulse wave velocity (PWV) (an important indicator of increased arterial stiffness). Increased arterial stiffness leads to decreased buffer function of arteries close to the cardiac and PWV, and increases systolic blood pressure and pulse (Dumor et al., 2018; S. Wu et al., 2019). It has been indicated that generally applied antihypertensive drugs are designed 
to reduce peripheral vascular resistance and have little role in altering the pathological process of vasoconstriction and hypertension (Sun, 2015). Meanwhile, the role of exercise and PA has been proven to be a safe and cost-effective approach in the prevention, control, and treatment of hypertension through various mechanisms (Boutcher \& Boutcher, 2017; Moore et al., 2016; Sharman et al., 2019). Using the results of several meta-analyses, researchers have determined that aerobic or resistance exercise can reduce systolic blood pressure by 6 to $8 \mathrm{~mm} \mathrm{Hg}$ (MacDonald et al., 2016; Tsukiyama et al., 2017). The study by Daniel and colleagues in 2019 also reported that 12 weeks of combined exercise (aerobic and resistance) played an effective role in controlling blood pressure in the elderly (Umpierre et al., 2019). In recent years, many studies have been conducted to understand the mechanisms of hypertensive response to exercise (HRE). One of the most important HRE mechanisms is attributed to the improvement of exercise-induced endothelial function. In fact, in response to increased shear stress caused by exercise, peripheral vascular resistance decreases, which is associated with improved vasodilation and endothelial function and plays a key role in controlling blood pressure (Kim \& Ha, 2016). Also, exercise improves vasodilation and controls blood pressure by increasing the expression and activity of nitric oxide (NO) (Kushkestani et al., 2020; Otsuki et al., 2020; Tzemos et al., 2015). On the other hand, studies have shown that the reverse relationship between exercise and stiffness of large arteries (Kim \& Ha, 2016). In addition, exercise can help to prevent, control, and even treat hypertension by improving the function of the renin-angiotensin-aldosterone system (Jing, 2017; Lelbach \& Koller, 2017). Other mechanisms such as improved glucose metabolism, sympathetic nerve activity, increased insulin sensitivity and improved structural and functional cardiac markers in response to exercise also lead to blood pressure control (Sabbahi et al., 2016).

\subsection{Type 2 diabetes}

Type 2 diabetes is another NCD and its risk increases with age. Elderly people are at greater risk for diabetes and related complications due to a combination of risk factors such as decreased mobility, malnutrition as well as genetic factors (Tang et al., 2020). The World Health Organization (WHO) (2018) referred to diabetes as the seventh leading cause of mortality (1.6 million deaths in 2016) worldwide (WHO, 2018). Previous researches clearly showed that exercise and PA are some of the most effective ways to prevent and treat type 2 diabetes (Kirwan et al., 2017; Kushkestani et al., 2020). Exercise mainly prevents type 2 diabetes and its associated complications in elderly people by improving glucose metabolism, body composition, lipid profile and many molecular- 
cellular pathways associated with insulin sensitivity (Tang et al., 2020). Increased insulin sensitivity and glucose transporter-4 concentration (GLUT-4) are some of the most important mechanisms involved in hypoglycemia in diabetic people in response to exercise (Kirwan et al., 2017). On the other hand, increased oxidative stress is also one of the most important causes of the incidence and development of diabetes mellitus, especially in elderly people. It is well proved that aerobic exercise plays an effective role in the treatment of diabetic elderly people by improving redox status, increasing antioxidants such as glutathione, and decreasing oxidative stress-induced insulin resistance (Yaribeygi et al., 2019). Previous studies have shown that a combination of moderate-tohigh-intensity aerobic and resistance exercise for 5 days a week had the highest benefits in terms of lowering blood sugar and reactive oxygen species (ROS) (Poblete-Aro et al., 2018), improving lipid profile (Kumar, 2018) and other types 2 diabetes-related complications in diabetic elderly people (Colberg et al., 2016).

\subsection{Metabolic syndrome}

MetS is a multifactorial disorder that increases the risk of CVDs and diabetes (Kassi et al., 2011). Many studies have shown that PA and exercise are the most effective way to prevent and control MetS-related risk factors (S.-H. Chang et al., 2019; Zhang et al., 2017). Aerobic exercise plays an important role in controlling and lowering blood glucose in elderly people by increasing glucose metabolism and improving the function of pancreatic beta cells (Kirwan et al., 2017). On the other hand, increasing lipid levels is one of the most important causes of MetS and associated diseases. It has also been reported that exercise leads to the prevention, control, and treatment of MetS in elderly people by increasing basal metabolic rate (BMR), maintaining muscle mass, reducing adipose tissue, and weight control (Beavers et al., 2018; Paley \& Johnson, 2018). In other terms, hypertension, as one of MetS symptoms, is the most important risk factor for mortality in the world (Xu et al., 2019) and it has been well established that aerobic exercises can prevent hypertension and associated CVDs in elderly people by increasing nitric oxide (NO) expression and improving vascular dilation (Ferrari et al., 2017).

\subsection{Osteoarthritis}

Osteoarthritis is known as one of the aging-related musculoskeletal disorders, a chronic longterm illness and the most important cause of disability in elderly people, characterized by resorption of articular cartilage, leading to bone fracture and stiffness, pain and motor disorder (Arden et al., 
2018). Aging is known to be the most important cause of osteoarthritis, but it can be prevented by modifying risk factors such as obesity and inactivity (Loeser, 2017). There is growing evidence that PA and exercise, especially low-to-moderate-intensity, play an essential role in preventing diseases among elderly people (Y. Wu et al., 2019; Zampogna et al., 2020). For instance, aerobic exercise, such as swimming modulates hypertension through losing weight. Other researchers investigate mechanisms underlying the effect of exercise on osteoarthritis show that mechanical stimulation induced by moderate-to-high-intensity exercises results in increased synthesis of cartilage matrix components, suppression of expression of inflammatory factors, and reduction of enzymes involved in articular cartilage destruction, including interleukin-1 $\beta$ (IL-1) and tumor necrosis factor- $\alpha$ (TNF), and matrix metalloproteinase (MMPS) enzymes (Villafañe, 2018). Aerobic and resistance exercises can prevent osteoarthritis by increasing the content of proteoglycans (the major components of cartilage extracellular matrix (ECM) (Castrogiovanni \& Musumeci, 2016).

\subsection{Geriatric syndrome}

As mentioned earlier, the aging syndrome is one of the most important causes of decreased quality of life and mortality among elderly people. Today, as the world's elderly population and the prevalence of aging syndrome continue to grow, researchers are focusing on preventing and controlling the symptoms of the syndrome. In the meantime, previous studies showed the positive effects of PA and exercise in preventing and improving many symptoms of aging, such as falls, cognitive impairments, fatigue and musculoskeletal disorders (Cartee et al., 2016; Kushkestani et al., 2020, 2020, 2020; Kushkestani, Parvani, Nosrani, \& Rezaei, 2020b; McPhee et al., 2016). In this section, we intend to investigate the most important mechanisms involved in improving these factors in response to exercise and PA.

\subsection{Sarcopenia}

Sarcopenia syndrome is characterized by a decrease in muscle size and strength, which plays an important role in the development of disorders such as cachexia, osteoporosis, disability, and mortality in elderly people (del Campo Cervantes et al., 2019; Yoo et al., 2018). Various factors and pathways, including environmental causes, endocrine problems (Vitale et al., 2016), increased oxidative stress (Can et al., 2017), motor neuron loss (Kwon \& Yoon, 2017), impaired mitochondrial function (Picca et al., 2019), activation of inflammatory signaling pathways (Dalle et al., 2017), and 
reduction in satellite cell (Snijders \& Parise, 2017) are involved in the pathogenesis of sarcopenia in the elderly people. Aerobic exercise can prevent the incidence and development of sarcopenia by increasing biogenesis and mitochondrial dynamics, decreasing the expression of catabolic genes, and increasing protein synthesis in muscles (Erlich et al., 2016; Seo et al., 2016). Besides, Liang et al. (2020) reported that aerobic exercises resulted in suppression of apoptotic pathways and increased expression of autophagy genes in skeletal muscles, thereby improving skeletal muscle function and preventing sarcopenia (Liang et al., 2020). On the other hand, resistance exercise is an important strategy to prevent a decrease in muscle mass and strength by stimulating hypertrophy and increasing muscle strength (Papa et al., 2017). Parry et al. (2020) reported that resistance exercise plays an effective role in improving muscle function and preventing sarcopenia in elderly people by increasing the size and cross-sectional area of muscle fibers (especially fast-twitch fibers) and suppressing myostatin gene expression (involved in reducing muscle protein synthesis) (Parry et al., 2020). Also, Lichtenberg et al. 2019 reported that 28 weeks of high-intensity resistance training led to increase skeletal muscle mass, handgrip strength and sarcopenia Z-score in the elderly with osteosarcopenia (Lichtenberg et al., 2019).

\subsection{Fall}

Fall is the sixth leading cause of death (Finlayson \& Peterson, 2010) and the main Cause fatal injuries, that require hospital admission in elderly (Pahor, 2019). It is well proved that impaired vision, musculoskeletal disorders, and impaired balance are the most important risk factors for falls in elderly people (Kushkestani, Parvani, Nosrani, \& Rezaei, 2020b; Liu-Ambrose et al., 2019; Zhou et al., 2019). According to the American College of Sports Medicine (ACSM), balance exercises are helpful in preventing falls in elderly people by improving proprioception and neuromuscular function (Sherrington et al., 2017; Y. Wu et al., 2019). Besides, increasing PA levels through light aerobic and resistance exercises, not only reduce inflammatory factors and improve neuromuscular function but also plays an effective role in preventing bone density reduction and the risk of falls in elderly people (Kemmler et al., 2018).

\subsection{Dementia}

Dementia is a neurological disorder and a comprehensive term that covers a variety of neurological damage which considerably affects a person's cognitive function and ability to perform 
daily activities (Smith, 2016). In other words, preserving cognitive status (CR) refers to the ability of the brain to resist age-related injuries and brain-related diseases (Arvanitakis \& Bennett, 2019). Predominantly, mental and physical stimulations in the early stage and throughout life preserve cognitive function and protect against dementia as well as delays it in the elderly (Wang et al., 2017). According to the World Health Organization in 2020, about 50 million people worldwide suffer from dementia, which is predicted to reach more than 152 million by 2050 (WHO, 2020). The positive role of exercise and PA in preventing brain deterioration has been well established (Alty et al., 2020; Rutten, 2017; Zheng et al., 2016). There is abundant evidence that increasing PA by improving the function of the body's immune systems and enhancing housekeeping systems plays a fundamental role in preventing cognitive decline and reducing the risk of brain degeneration in the elderly (McGurran et al., 2019; Mortimer \& Stern, 2019; Skinner et al., 2018). In addition, it has been reported that increased levels of PA, especially through aerobic exercises such as running and swimming improve risk factors for cerebrovascular disease, increase the volume of the hippocampus and enhance cognitive network performance of the elderly brain and subsequently, cause to decrease the risk of dementia (Norman et al., 2018). On the other hand, it has been demonstrated that neuroplasticity of the brain is one of the primary mechanisms of learning, memory, and cognitive processes in humans (Müllers et al., 2019; Norman et al., 2018). In this regard, animal studies have reported that exercise can improve cognitive performance and prevent dementia via increasing the expression of synaptic plasticity genes, such as synapsin I and synaptophysin, and various neuroplastic transcription factors, including cyclic adenosine monophosphate response elementbinding and intracellular kinases. Exercise also increases the hippocampal dendritic length and dendritic spine complexity and neurogenesis of the hippocampal dentate gyrus, which plays a pivotal role in the prevention of neurodegenerative diseases, especially dementia. On the other hand, human studies show that brain dependent nuclear factor (BDNF) is one of the important neurological factors in cognitive processes. BDNF levels are reduced in people with cognitive impairments such as dementia and Alzheimer's. BDNF also rapidly passes over the blood-brain barrier, so circulating levels can be related to the brain. Exercise is associated with an increase in BDNF levels, thereby playing an important role in cognitive process improvement and slowing down brain aging (Alty et al., 2020; Norman et al., 2018). 


\section{GUIDELINE OF EXERCISES}

It is clear that training variables such as type, intensity, duration and frequency of exercise are crucial factors in physiological and anatomical adaptations. In this review article and according to the literature, we have shown that various training (aerobic and resistance) as well as High Intensity Interval Training (HIIT) training play important roles in the prevention and management of age-related diseases and syndromes. In Table 1, the appropriate exercises for elderly are presented to prevent aging disorders and to gain the best health benefits for Successful aging.

Table 1. Guidelines of exercises for healthy older adults

\begin{tabular}{|c|c|c|c|}
\hline Variables & Aerobic & Resistance & HIIT \\
\hline Frequency & 3-5 days per week & 2-3 days per week & 3-5 days per week \\
\hline Intensity & Moderate to high & Light to moderate & High \\
\hline Time & $\begin{array}{l}\text { A minimum of } 30 \text { minutes or up to } 60 \\
\text { minutes per day }(\mathrm{m} / \mathrm{d}) \text { for moderate } \\
\text { intensity aerobic exercise or at least } 20 \\
\text { to } 30 \mathrm{~m} / \mathrm{d} \text { for vigorous intensity. }\end{array}$ & $\begin{array}{l}8-10 \text { exercises involving the } \\
\text { major muscle groups; } 1-3 \text { sets of } \\
8-12 \text { repetitions each }\end{array}$ & 20-30 Min per session \\
\hline Type & $\begin{array}{l}\text { Any modality that does not impose } \\
\text { excessive orthopedic stretch such as } \\
\text { walking. Aquatic exercise and stationary } \\
\text { cycle exercise may be advantageous for } \\
\text { those with limited tolerance for weight- } \\
\text { bearing activity. }\end{array}$ & $\begin{array}{l}\text { Progressive weight-training } \\
\text { programs or weight-bearing } \\
\text { callisthenic, stair climbing, and } \\
\text { other strengthening activities } \\
\text { that use the major muscle } \\
\text { groups }\end{array}$ & $\begin{array}{l}\text { Any physical activities that } \\
\text { increase the heart rate in a } \\
\text { short time. These exercises } \\
\text { can be done by equipment } \\
\text { or bodyweight exercises. }\end{array}$ \\
\hline
\end{tabular}

Table 2. Suggested exercise for preventing, controlling and treating aging-related diseases and geriatric syndromes in various subjects

\begin{tabular}{|c|c|c|c|c|}
\hline Disease & Authors & Short topic & Subjects & Results and conclusion \\
\hline & $\begin{array}{l}\text { Altavilla et al., } \\
2018 \text { (Brief } \\
\text { review) }\end{array}$ & $\begin{array}{c}\text { Physical activity } \\
\text { in cardiovascular } \\
\text { patients }\end{array}$ & $\begin{array}{l}\text { Cardiovascular } \\
\text { patients (Focus on } \\
\text { the older adults) }\end{array}$ & $\begin{array}{l}\text { A physical activity program found a } \\
\text { sure indication both in elderly subjects } \\
\text { without and with pathologies and in } \\
\text { the elderly with high risk of disability }\end{array}$ \\
\hline $\begin{array}{l}\text { Cardiovascular } \\
\text { diseases }\end{array}$ & $\begin{array}{l}\text { Barengo et al., } \\
2017 \text { (Original) }\end{array}$ & $\begin{array}{l}\text { Leisure time } \\
\text { physical activity } \\
\text { and } \\
\text { cardiovascular } \\
\text { diseases }\end{array}$ & Older adults & $\begin{array}{l}\text { Baseline LTPA reduces the risk of } \\
\text { total and CVD mortality and incident } \\
\text { CVD events in older adults } \\
\text { independently of the major known } \\
\text { CVD risk factors. }\end{array}$ \\
\hline
\end{tabular}


$\begin{array}{ll}\text { Bouaziz et al., } & \text { Aerobic training } \\ 2017 \text { (Review) } & \text { in older adults }\end{array}$
Aerobic training (Especially moderate intensity) can be considered as a safe way to develop cardiac health and quality of life in older adults.

$\begin{array}{ccc}\begin{array}{c}\text { Recchioni et al., } \\ 2017 \text { (Review) }\end{array} & \begin{array}{c}\text { Physical activity } \\ \text { in the elderly with } \\ \text { cardiovascular } \\ \text { diseases. }\end{array} & \begin{array}{c}\text { Older adults } \\ \text { (Cardiovascular } \\ \text { patients) }\end{array}\end{array}$

Physical activity has emerged as an important non-pharmacological adjunctive therapy for CVD in older patients, especially for heart failure patients, exerting its beneficial effects on mortality, morbidity, and functional capacity.

\begin{tabular}{ccc}
\hline $\begin{array}{c}\text { Roh et al., 2016 } \\
\text { (Review) }\end{array}$ & $\begin{array}{c}\text { Exercise in } \\
\text { cardiac aging }\end{array}$ & Older adults \\
\hline $\begin{array}{c}\text { Pandey et al., } \\
2017 \text { (Original) }\end{array}$ & $\begin{array}{c}\text { Endurance } \\
\text { training and heart } \\
\text { failure in the } \\
\text { elderly }\end{array}$ & $\begin{array}{c}\text { Older adults } \\
\text { (With heart } \\
\text { failure) }\end{array}$ \\
& $\begin{array}{c} \\
\end{array}$ &
\end{tabular}

This review has shown that exercise can have a positive role in the reduction of cardiac aging in older adults.
The change in $\mathrm{VO}_{2 \text { peak }}$ in response to endurance exercise training in older adults with HF differs significantly according to $\mathrm{HF}$ subtype, with greater

$\mathrm{VO}_{2 \text { peak }}$ improvement in HFpEF (preserved EF) than HFrEF (reduced ejection fraction).

\begin{tabular}{ccc}
\hline $\begin{array}{c}\text { Jakovljevic, } 2018 \\
\text { (Review) }\end{array}$ & $\begin{array}{c}\text { Physical activity } \\
\text { and }\end{array}$ & Older adults \\
& cardiovascular & \\
aging &
\end{tabular}

Not only that long lasting exercise training of several years and/or decades is associated with improved cardiovascular function in later life, but also exercise interventions performed by previously sedentary individuals provide a significant health benefits, and can reverse, to some extent, age-related decline in cardiovascular function further leading to improved quality of life and functional independence.

$\begin{array}{ccc}\text { Boutcher \& } & \begin{array}{c}\text { Exercise intensity } \\ \text { and hypertension }\end{array} & \begin{array}{c}\text { hypertensive } \\ \text { individuals }\end{array}\end{array}$

(Review)
Emerging evidence indicates that exercise performed at an intensity $>70 \%$ of $V_{-} \mathrm{O} 2 \mathrm{max}$ may have an important role in the control of hypertension. Both HIIT and regular aerobic exercise have been shown to reduce the BP of hypertensive individuals.

$\begin{array}{llc}\text { Sharman et al., } & \begin{array}{l}\text { Exercise and } \\ \text { hypertension }\end{array} & \begin{array}{c}\text { hypertensive } \\ \text { individuals }\end{array}\end{array}$

\section{Hypertension}

According to the evidence, It can be stated that regular exercise (Aerobic, resistance, high-intensity interval training), and isometric resistance training) has a positive role in the prevention, management, and even treatment of hypertension. 


\begin{tabular}{|c|c|c|c|}
\hline $\begin{array}{c}\text { MacDonald et } \\
\text { al., } 2016 \text { (A } \\
\text { systematic } \\
\text { review and Meta- } \\
\text { Analysis) }\end{array}$ & $\begin{array}{c}\text { Dynamic } \\
\text { resistance training } \\
\text { as a } \\
\text { antihypertensive } \\
\text { therapy }\end{array}$ & $\begin{array}{l}\text { Prehypertensive } \\
\text { and hypertensive } \\
\text { adults }\end{array}$ & $\begin{array}{l}\text { Results indicated that for nonwhite } \\
\text { adult samples with hypertension, } \\
\text { dynamic RT may elicit BP reductions } \\
\text { that are comparable to or greater than } \\
\text { those reportedly achieved with AE } \\
\text { training. }\end{array}$ \\
\hline $\begin{array}{c}\text { Tsukiyama et al., } \\
2017 \text { (Original) }\end{array}$ & $\begin{array}{l}\text { Exercise training } \\
\text { and blood } \\
\text { pressure markers }\end{array}$ & Middle aged & $\begin{array}{l}\text { Aerobic exercise training increased } \\
\text { NO generation, reduced blood } \\
\text { pressure, and induced anti-oxidant } \\
\text { enzymes via SIRT3, and suggest that } \\
\text { exercise training may be an important } \\
\text { factor for the prevention of disease by } \\
\text { inducing intrinsic NO and anti-oxidant } \\
\text { enzymes. }\end{array}$ \\
\hline
\end{tabular}

\begin{tabular}{|c|c|c|c|}
\hline $\begin{array}{l}\text { Umpierre et al., } \\
2019 \text { (Study } \\
\text { protocol) }\end{array}$ & $\begin{array}{l}\text { Hypertension } \\
\text { approaches in the } \\
\text { elderly }\end{array}$ & $\begin{array}{l}\text { Hypertensive } \\
\text { older adults }\end{array}$ & $\begin{array}{l}\text { Combined training played an effective } \\
\text { role in controlling blood pressure in } \\
\text { the elderly. }\end{array}$ \\
\hline $\begin{array}{l}\text { Otsuki et al., } \\
2020 \\
\text { (Original) }\end{array}$ & $\begin{array}{l}\text { Combined } \\
\text { training and NO } \\
\text { and arterial } \\
\text { stiffness }\end{array}$ & Older adults & $\begin{array}{c}\text { Combined training (Aerobic and } \\
\text { resistance) increased aerobic capacity, } \\
\text { muscle strength, and plasma } \\
\text { concentrations of nitrite/nitrate (end } \\
\text { products of NO) and decreased pulse } \\
\text { wave velocity (an index of arterial } \\
\text { stiffness) without changes in body } \\
\text { weight. }\end{array}$ \\
\hline
\end{tabular}

$\begin{array}{ccc}\text { Lelbach \& } & \text { Mechanisms of } & \text { Healthy and } \\ \text { Koller, 2017 } & \text { exercise on } & \text { hypertensive } \\ \text { (Review) } & \text { hypertension } & \text { subjects }\end{array}$
Aerobic, Resistance and concurrent exercise training (involving both aerobic and resistance exercises) increase expression of vasodilator genes and decrease arterial stiffness, so it can play an important role in treat, management and prevention of hypertension in different age.

\begin{tabular}{ccc}
\hline Sabbahi et al., & $\begin{array}{c}\text { Exercise and } \\
\text { vascular control }\end{array}$ & $\begin{array}{c}\text { Healthy and } \\
\text { hypertensive } \\
\text { subjects }\end{array}$
\end{tabular}

Aerobic, resistance, and combined exercise training can be helpful in the management or prevention of hypertension by enhancing vascular function, alter the vascular structure, decrease arterial stiffness and, improve the function of the autonomic nervous system.

$\begin{array}{ccc}\text { Kirwan et al., } & \text { Exercise and } & \text { Type } 2 \text { diabetic } \\ 2017 \text { (Review) } & \text { management of } & \text { patients }\end{array}$
T2D
Both aerobic and resistance training can have a role in the reduction of $\mathrm{HbA1C}$, insulin resistance, fasting blood glucose, Increasing VO2max, improved lipid profile, and liver function. So, these programs promote healthier skeletal muscle, adipose tissue, liver, and pancreatic function and have an important role in the management of T2D. 


$\begin{array}{ccc}\text { Yaribeygi et al., } & \begin{array}{c}\text { Aerobic training } \\ \text { and insulin } \\ \text { sensitivity }\end{array} & \begin{array}{c}\text { Type } 2 \text { diabetes } \\ \text { patients }\end{array}\end{array}$

The available data suggest that $\mathrm{AE}$ increases insulin sensitivity in peripheral tissues, leading to improved glucose homeostasis and a reduction in insulin resistance through at least seven different molecular mechanisms and so prevent T2DM.

\begin{tabular}{ccc}
\hline $\begin{array}{c}\text { Poblete-Aro et } \\
\text { al., 2018 } \\
\text { (Review) }\end{array}$ & $\begin{array}{c}\text { Exercise and } \\
\text { oxidative stress in } \\
\text { T2D }\end{array}$ & $\begin{array}{c}\text { Type 2 diabetes } \\
\text { patient }\end{array}$ \\
& & \\
\hline $\begin{array}{c}\text { Colberg et al., } \\
\text { 2016 (Position } \\
\text { statement) }\end{array}$ & $\begin{array}{c}\text { Physical activity, } \\
\text { exercise and } \\
\text { diabetes }\end{array}$ & $\begin{array}{c}\text { Type 2 diabetes } \\
\text { patient }\end{array}$ \\
\hline
\end{tabular}

This study showed that exercise training has a positive role by reduction of oxidative stress markers and creating the balance between oxidant and antioxidant pathways in the management of T2D.

Physical activity and exercise should be recommended and prescribed to all individuals with diabetes as part of management of glycemic control and overall health. Exercise programs should be containing aerobic, resistance, flexibility and balance training with moderate intensity and $>3$ days per week.

$\begin{array}{ccc}\text { S.-H. Chang et } & \text { Lifestyle } & \text { Older adults } \\ \text { al., 2019 } & \text { intervention in the } & \text { (With metabolic } \\ \text { (Original) } & \text { elderly } & \text { syndrome) }\end{array}$

This intervention strategy successfully improved several important health related parameters in participants such as BW, BMI, WC, and BP. The experimental group with exercise and diet intervention could promote more metabolic changes than the control group.

\begin{tabular}{ccc}
\hline Paley et al., 2018 & Exercise as a & Adults \\
(Review) & $\begin{array}{c}\text { medicine for } \\
\text { metabolic } \\
\text { syndrome }\end{array}$ &
\end{tabular}

\section{Metabolic syndrome}

\begin{tabular}{|c|c|c|}
\hline $\begin{array}{c}\text { Zhang et al., } \\
2017 \text { (Meta- } \\
\text { analysis) }\end{array}$ & $\begin{array}{l}\text { Leisure time } \\
\text { Physical activity } \\
\text { and metabolic } \\
\text { syndrome }\end{array}$ & Adults \\
\hline
\end{tabular}




$\begin{array}{ccc}\begin{array}{c}\text { Zampogna et al., } \\ 2020 \text { (Review) }\end{array} & \begin{array}{c}\text { Physical activity } \\ \text { and hip and knee } \\ \text { osteoarthritis }\end{array} & \begin{array}{c}\text { Older adults } \\ \text { (With knee or hip } \\ \text { osteoarthritis) }\end{array}\end{array}$

Compared to controls, Aquatic Exercise, Land-based Exercise, Tai Chi, and Yoga showed a small to high effect for improving pain, physical function, quality of life, and stiffness. Active exercise and sport are effective to improve pain and physical function in elderly people with osteoarthritis.

Villafañe, $2018 \quad$ Exercise and

(Editorial letter) osteoarthritis

\section{Osteoarthritis}

People with OA
or having
symptoms of OA

Exercise therapy has moderate positive benefits for people with symptomatic

OA. Muscle strengthening and programs that include combinations of strength, flexibility, and aerobic exercises, are more beneficial for pain and disability than general activity (e.g., walking).

$\begin{array}{ccc}\text { Castrogiovanni et } & \text { The best physical } & \text { OA Patients } \\ \text { al, 2016 } & \text { treatment for } & \\ \text { (Review) } & \text { osteoarthritis } & \end{array}$

\section{Sarcopenia}

Exercise programs that combine strengthening exercise with exercise that increases flexibility and aerobic capacity seem to be the "best" option that it is offered to patients with mild

$\mathrm{OA}$, for taking into account their preferences and tolerance. $\begin{array}{ccc}\begin{array}{c}\text { Liang et al., } 2020 \\ \text { (Review) }\end{array} & \begin{array}{c}\text { Exercise-induced } \\ \text { autophagy for } \\ \text { sarcopenia }\end{array} & \text { Older adults }\end{array}$
Both modes of exercise (Aerobic and resistance) can regulate the functional status of autophagy to improve tissue regeneration in aged individuals, attenuate the aging-related decline in skeletal muscle regenerative function. Nevertheless, overtraining can cause excessive activation of autophagy and induce atrophy-related gene expression in skeletal muscle. So, it should be noted that moderate-intensity training can be safe in terms of the prevention of sarcopenia by autophagy pathways.

$\begin{array}{ccc}\begin{array}{c}\text { Papa et al., 2017 } \\ \text { (Review) }\end{array} & \begin{array}{c}\text { Resistance } \\ \text { training and } \\ \text { skeletal muscle } \\ \text { function }\end{array} & \text { Older adults } \\ & & \end{array}$
Resistance training with moderate intensity can attenuate skeletal muscle function deficits in older adults. Older adults should be encouraged to participate in progressive resistance training activities, and should be admonished to move along a continuum of exercise from immobility, toward the recommended daily amounts of activity.




2019 (Original) $\begin{array}{ccc}\text { Lichtenberg et al. } & \begin{array}{c}\text { High-Intensity } \\ \text { Interval Training } \\ \text { on Sarcopenia }\end{array} & \begin{array}{c}\text { Older adults (with } \\ \text { osteosarcopenia) }\end{array}\end{array}$

The results clearly confirm the favorable effects of high-intensity resistance training (HI-RT) on sarcopenia. We conclude that HI-RT is a feasible, highly efficient and safe training modality for combating sarcopenia, also in the elderly. The results show a significant effect of the exercise intervention on the sarcopenia Z-score, $d$ a significant increase of skeletal muscle mass index (SMI) and a significant intergroup difference of SMI and handgrip strength.

\begin{tabular}{ccc}
\hline Del Campo & Resistance & Older adults \\
Cervantes et al., & $\begin{array}{c}\text { training program } \\
\text { on sarcopenia and } \\
\text { functionality }\end{array}$ & (with sarcopenia) \\
& $\begin{array}{c} \\
\end{array}$ &
\end{tabular}

Kushkestani, Parvani, Nosrani, \& Rezaei, 2020b

(Original) Physical activity
and fall risk
12 weeks of resistance training led to a significant increase in muscle strength, an improvement in physical performance, in balance, chair stand and gait speed. So, the resistance training program improves the functionality (muscle strength and physical performance), with the benefit of the decrease in severe sarcopenia.

Based on the resulting positive relationship between physical activity (all of subscales of its domains) and falls, it can be stated that the using strategies such as increasing sports environments with a focus on exercise, physiologists can play an effective role in preventing falls and related complications in the elderly.

\section{Y. Wu et al., 2019 (Book)}

Healthy aging and

exercise
Older adults

Doing regular training with moderate intensity especially balance training can have a preventive role in falls through many mechanisms in older adults.
Sherrington et al. 2017 (Review)
Exercise and prevention of falls
Older adults

\footnotetext{
Exercise as a single intervention can prevent falls in community-dwelling older people. Exercise programs that challenge balance and are of a higher dose have larger effects. The impact of exercise as a single intervention in clinical groups and aged care facility residents require further investigation, but promising results are evident for people with Parkinson's disease and cognitive impairment.
} 


\begin{tabular}{|c|c|c|c|c|}
\hline & $\begin{array}{l}\text { Liu-Ambrose et } \\
\text { al. } 2019 \\
\text { (Original) }\end{array}$ & $\begin{array}{l}\text { Home-based } \\
\text { exercise program } \\
\text { on subsequent } \\
\text { falls }\end{array}$ & $\begin{array}{l}\text { Older adults } \\
\text { (High-risk of } \\
\text { falls) }\end{array}$ & $\begin{array}{l}\text { Home-based strength and balance } \\
\text { retraining exercise program for } 12 \\
\text { months significantly reduced the rate } \\
\text { of subsequent falls compared with } \\
\text { usual care provided by a geriatrician. } \\
\text { These findings support the use of this } \\
\text { home-based exercise program for } \\
\text { secondary fall prevention but require } \\
\text { replication in other clinical settings. }\end{array}$ \\
\hline \multirow{5}{*}{ Dementia } & $\begin{array}{l}\text { Alty et al., } 2020 \\
\text { (Review) }\end{array}$ & $\begin{array}{l}\text { Exercise and } \\
\text { dementia } \\
\text { prevention }\end{array}$ & Older adults & $\begin{array}{l}\text { Exercise and other physical activity are } \\
\text { important for brain health. Increasing } \\
\text { physical activity is a promising non- } \\
\text { pharmacological intervention to delay } \\
\text { the cognitive manifestations of ageing } \\
\text { and to reduce the risk of dementia. }\end{array}$ \\
\hline & $\begin{array}{l}\text { Rutten, } 2017 \\
\text { (Review) }\end{array}$ & $\begin{array}{l}\text { Can exercise } \\
\text { prevent falls? }\end{array}$ & Older adults & $\begin{array}{l}\text { Physical exercise in older adults has } \\
\text { shown to be beneficial for } \\
\text { enhancement of cognitive functions } \\
\text { such as memory and learning. }\end{array}$ \\
\hline & $\begin{array}{l}\text { Zheng et al., } \\
2016 \text { (A } \\
\text { systematic } \\
\text { review and meta- } \\
\text { analysis) }\end{array}$ & $\begin{array}{l}\text { Aerobic training } \\
\text { ameliorates } \\
\text { cognitive function }\end{array}$ & $\begin{array}{l}\text { Older adults with } \\
\text { mild cognitive } \\
\text { impairment } \\
\text { (MCI) }\end{array}$ & $\begin{array}{l}\text { The moderate-intensity aerobic } \\
\text { exercise more than } 12 \text { weeks led to an } \\
\text { improvement in global cognitive } \\
\text { ability and had a positive effect with a } \\
\text { small effect size on memory in people } \\
\text { with MCI. }\end{array}$ \\
\hline & $\begin{array}{l}\text { McGurran et al., } \\
2019 \text { (Review) }\end{array}$ & $\begin{array}{l}\text { Prevention and } \\
\text { Treatment of } \\
\text { Alzheimer's } \\
\text { Disease }\end{array}$ & Older adults & $\begin{array}{c}\text { Regular aerobic and resistance training } \\
\text { provides a non-invasive way of } \\
\text { influencing multiple mechanisms that } \\
\text { have been shown to alter AD } \\
\text { pathology. Exercise alone will not be } \\
\text { sufficient to prevent } \mathrm{AD} \text {, but it serves } \\
\text { as a foundation for non- } \\
\text { pharmacological lifestyle } \\
\text { interventions. }\end{array}$ \\
\hline & $\begin{array}{c}\text { Mortimer \& } \\
\text { Stern, 2019 } \\
\text { (Editorial letter) }\end{array}$ & $\begin{array}{l}\text { Exercise and } \\
\text { physical activity } \\
\text { decrease the risk } \\
\text { of dementia }\end{array}$ & All ages & $\begin{array}{l}\text { Lifestyle interventions such as physical } \\
\text { exercise may provide inexpensive and } \\
\text { effective ways to delay the onset of } \\
\text { cognitive decline and dementia. }\end{array}$ \\
\hline
\end{tabular}




\begin{tabular}{|c|c|c|c|}
\hline $\begin{array}{l}\text { Norman et al., } \\
2018 \text { (Review) }\end{array}$ & $\begin{array}{c}\text { Exercise and } \\
\text { cognitive } \\
\text { protection }\end{array}$ & Older adults & $\begin{array}{l}\text { Moderate physical exercise with } \\
\text { training appears to be a moderator } \\
\text { lifestyle factor which can provide } \\
\text { benefits to cognitive function. Exercise } \\
\text { has been demonstrated to preserve } \\
\text { white and gray matter, induce changes } \\
\text { in the hippocampus, including } \\
\text { neurogenesis, and improve cognitive } \\
\text { function. Increased expression of } \\
\text { BDNF, PGC-1 } \alpha \text { signaling, and altered } \\
\text { skeletal muscle IL-6 production appear } \\
\text { to mediate some of the benefits of } \\
\text { exercise for cognitive function. }\end{array}$ \\
\hline $\begin{array}{l}\text { Müllers et al., } \\
2019 \\
\text { (Perspective } \\
\text { article) }\end{array}$ & $\begin{array}{c}\text { Exercise as a } \\
\text { medicine for } \\
\text { dementia } \\
\text { prevention }\end{array}$ & Adults & $\begin{array}{l}\text { Exercise interventions should be } \\
\text { intensive enough to increase lactate } \\
\text { and, as a consequence, BDNF. } \\
\text { However, especially in older adults, } \\
\text { classical exercise interventions rarely } \\
\text { achieve the second ventilatory } \\
\text { threshold (VT2) level, which is } \\
\text { associated with an accumulation of } \\
\text { lactate. Using High-Intensity Interval } \\
\text { Training (HIIT) with higher intensities } \\
\text { and lower volumes could be a method } \\
\text { to achieve higher numbers of } \\
\text { responders. In conclusion, intensity is } \\
\text { an important variable to improve } \\
\text { cognitive function and prevent of } \\
\text { dementia. }\end{array}$ \\
\hline
\end{tabular}

\section{CONCLUSIONS AND CLINICAL IMPLICATIONS}

According to the literature and the role of exercise in the prevention, control, and treatment of many diseases and aged associated syndromes, it can be stated that exercise is a safe, cost-effective and free of side effects approach which not only can be used in the treatment of a Pathology, but also it improves the function of other systems and organs of the body. However, the following considerations should be viewed when an exercise prescription is provided to treat and the PA level up is targeted in the elderly: First, it is important to pay attention to the type of exercise (aerobic, resistance or other activity), intensity, frequency as well as the duration of the training period in order to reach the desired goal in the elderly. Second of all is elderly conditions (healthy, frail, disabled, etc.) that play an important role in applying the exercise protocol. 


\section{REFERENCES}

1. Altavilla, G., D'Elia, F., \& Raiola, G. (2018). A brief review of the effects of physical activity in subjects with cardiovascular disease: An interpretative key. Sport Mont, 16(3), 103-106.

2. Alty, J., Farrow, M., \& Lawler, K. (2020). Exercise and dementia prevention. Practical Neurology, 20(3), 234-240.

3. Arden, N., Blanco, F. J., \& Bruyère, O. (2018). Epidemiology of osteoarthritis. Atlas of Osteoarthritis, 18.

4. Arias, I. M., Alter, H. J., Boyer, J. L., Cohen, D. E., Shafritz, D. A., Thorgeirsson, S. S., \& Wolkoff, A. W. (2020). The liver: Biology and pathobiology. John Wiley \& Sons.

5. Arvanitakis, Z., \& Bennett, D. A. (2019). What Is Dementia? Jama, 322(17), 1728-1728.

6. Baijens, L. W., Clavé, P., Cras, P., Ekberg, O., Forster, A., Kolb, G. F., Leners, J.-C., Masiero, S., Mateos-Nozal, J., \& Ortega, O. (2016). European Society for Swallowing Disorders-European Union Geriatric Medicine Society white paper: Oropharyngeal dysphagia as a geriatric syndrome. Clinical Interventions in Aging, 11, 1403.

7. Barengo, N. C., Antikainen, R., Borodulin, K., Harald, K., \& Jousilahti, P. (2017). Leisuretime physical activity reduces total and cardiovascular mortality and cardiovascular disease incidence in older adults. Journal of the American Geriatrics Society, 65(3), 504-510.

8. Beavers, K. M., Walkup, M. P., Weaver, A. A., Lenchik, L., Kritchevsky, S. B., Nicklas, B. J., Ambrosius, W. T., Stitzel, J. D., Register, T. C., \& Shapses, S. A. (2018). Effect of exercise modality during weight loss on bone health in older adults with obesity and cardiovascular disease or metabolic syndrome: A randomized controlled trial. Journal of Bone and Mineral Research, 33(12), 2140-2149.

9. Bouaziz, W., Vogel, T., Schmitt, E., Kaltenbach, G., Geny, B., \& Lang, P. O. (2017). Health benefits of aerobic training programs in adults aged 70 and over: A systematic review. Archives of Gerontology and Geriatrics, 69, 110-127.

10. Boutcher, Y. N., \& Boutcher, S. H. (2017). Exercise intensity and hypertension: What's new? Journal of Human Hypertension, 31(3), 157-164.

11. Can, B., Kara, O., Kizilarslanoglu, M. C., Arik, G., Aycicek, G. S., Sumer, F., Civelek, R., Demirtas, C., \& Ulger, Z. (2017). Serum markers of inflammation and oxidative stress in sarcopenia. Aging Clinical and Experimental Research, 29(4), 745-752.

12. Carmona, J. J., \& Michan, S. (2016). Biology of healthy aging and longevity. Revista de Investigacion Clinica, 68(1), 7-16. 
13. Cartee, G. D., Hepple, R. T., Bamman, M. M., \& Zierath, J. R. (2016). Exercise promotes healthy aging of skeletal muscle. Cell Metabolism, 23(6), 1034-1047.

14. Castrogiovanni, P., \& Musumeci, G. (2016). Which is the best physical treatment for osteoarthritis? Journal of Functional Morphology and Kinesiology, 1(1), 54-68.

15. Chang, A. Y., Skirbekk, V. F., Tyrovolas, S., Kassebaum, N. J., \& Dieleman, J. L. (2019). Measuring population ageing: An analysis of the global burden of disease study 2017. The Lancet Public Health, 4(3), e159-e167.

16. Chang, S.-H., Chien, N.-H., \& Yu, C.-Y. (2019). Long-Term Lifestyle Intervention in Elderly with Metabolic Syndrome. Clinical Nursing Research, 28(6), 658-675.

17. Cheung, J. T., Yu, R., Wu, Z., Wong, S. Y., \& Woo, J. (2018). Geriatric syndromes, multimorbidity, and disability overlap and increase healthcare use among older Chinese. BMC Geriatrics, 18(1), 147.

18. Colberg, S. R., Sigal, R. J., Yardley, J. E., Riddell, M. C., Dunstan, D. W., Dempsey, P. C., Horton, E. S., Castorino, K., \& Tate, D. F. (2016). Physical activity/exercise and diabetes: A position statement of the American Diabetes Association. Diabetes Care, 39(11), 2065-2079.

19. da Silva, V. D., Tribess, S., Meneguci, J., Sasaki, J. E., Garcia-Meneguci, C. A., Carneiro, J. A. O., \& Virtuoso, J. S. (2019). Association between frailty and the combination of physical activity level and sedentary behavior in older adults. BMC Public Health, 19(1), 1-6.

20. da Silveira Langoni, C., de Lima Resende, T., Barcellos, A. B., Cecchele, B., Knob, M. S., do Nascimento Silva, T., da Rosa, J. N., de Souza Diogo, T., da Silva Filho, I. G., \& Schwanke, C. H. A. (2019). Effect of exercise on cognition, conditioning, muscle endurance, and balance in older adults with mild cognitive impairment: A randomized controlled trial. Journal of Geriatric Physical Therapy, 42(2), E15-E22.

21. Dalle, S., Rossmeislova, L., \& Koppo, K. (2017). The role of inflammation in age-related sarcopenia. Frontiers in Physiology, 8, 1045.

22. Davalli, P., Mitic, T., Caporali, A., Lauriola, A., \& D’Arca, D. (2016). ROS, cell senescence, and novel molecular mechanisms in aging and age-related diseases. Oxidative Medicine and Cellular Longevity, 2016.

23. del Campo Cervantes, J. M., Cervantes, M. H. M., \& Torres, R. M. (2019). Effect of a resistance training program on sarcopenia and functionality of the older adults living in a nursing home. The Journal of Nutrition, Health \& Aging, 23(9), 829-836.

24. Dumor, K., Shoemaker-Moyle, M., Nistala, R., \& Whaley-Connell, A. (2018). Arterial stiffness in hypertension: An update. Current Hypertension Reports, 20(8), 72. 
25. Erlich, A. T., Tryon, L. D., Crilly, M. J., Memme, J. M., Moosavi, Z. S. M., Oliveira, A. N., Beyfuss, K., \& Hood, D. A. (2016). Function of specialized regulatory proteins and signaling pathways in exercise-induced muscle mitochondrial biogenesis. Integrative Medicine Research, 5(3), 187-197.

26. Ferrari, R., Umpierre, D., Vogel, G., Vieira, P. J., Santos, L. P., de Mello, R. B., Tanaka, H., \& Fuchs, S. C. (2017). Effects of concurrent and aerobic exercises on postexercise hypotension in elderly hypertensive men. Experimental Gerontology, 98, 1-7.

27. Finlayson, M. L., \& Peterson, E. W. (2010). Falls, aging, and disability. Physical Medicine and Rehabilitation Clinics, 21(2), 357-373.

28. Gill, S. (2015). Association between lifetime physical activity and cognitive functioning in middle-aged and older community dwelling adults: Results from the brain in motion study [Master's Thesis]. Graduate Studies.

29. Gomes, M., Figueiredo, D., Teixeira, L., Poveda, V., Paúl, C., Santos-Silva, A., \& Costa, E. (2017). Physical inactivity among older adults across Europe based on the SHARE database. Age and Ageing, 46(1), 71-77.

30. Gopinath, B., Kifley, A., Flood, V. M., \& Mitchell, P. (2018). Physical activity as a determinant of successful aging over ten years. Scientific Reports, 8(1), 1-5.

31. Harris, R. E. (2019). Epidemiology of chronic disease: Global perspectives. Jones \& Bartlett Learning.

32. Hurst, C., Weston, K. L., \& Weston, M. (2019). The effect of 12 weeks of combined upperand lower-body high-intensity interval training on muscular and cardiorespiratory fitness in older adults. Aging Clinical and Experimental Research, 31(5), 661-671.

33. Jakovljevic, D. G. (2018). Physical activity and cardiovascular aging: Physiological and molecular insights. Experimental Gerontology, 109, 67-74.

34. Jing, T. (2017). Association of RAAS Gene Polymorphisms and Effects of Different Intensity Aerobic Exercise on Blood Pressure in Men with Essential Hypertension. Journal of Beijing Sport University, 5, 8.

35. Kanasi, E., Ayilavarapu, S., \& Jones, J. (2016). The aging population: Demographics and the biology of aging. Periodontology 2000, 72(1), 13-18.

36. Kassi, E., Pervanidou, P., Kaltsas, G., \& Chrousos, G. (2011). Metabolic syndrome: Definitions and controversies. BMC Medicine, 9(1), 48. 
37. Kemmler, W., Shojaa, M., Kohl, M., \& Von Stengel, S. (2018). Exercise effects on bone mineral density in older men: A systematic review with special emphasis on study interventions. Osteoporosis International, 29(7), 1493-1504.

38. Kim, D., \& Ha, J.-W. (2016). Hypertensive response to exercise: Mechanisms and clinical implication. Clinical Hypertension, 22(1), 17.

39. Kirwan, J. P., Sacks, J., \& Nieuwoudt, S. (2017). The essential role of exercise in the management of type 2 diabetes. Cleveland Clinic Journal of Medicine, 84(7 Suppl 1), S15.

40. Kumar, R. (2018). The influence of physical exercise on lipid profile. Journal Current Science, 19(10).

41. Kushkestani, M., ENosrani, S., Parvani, M., \& Rezaei, S. (2020). The Relationship Between the Level of Physical Activity and Dementia in Elderly Residents of Nursing Homes in Tehran. Biomedical Journal of Scientific \& Technical Research, 29(3), 22437-22443.

42. Kushkestani, M., Moghadassi, M., Parvani, M., Nosrani, S. E. P., \& Rezaei, S. (2020). Physical Activity as a Preventive Factor to Aging-Related Physical Dysfunction in Iranian Community-Dwelling Elderly. Journal of Aging Science, 8.

43. Kushkestani, M., Parvani, M., Bathaeezadeh, S. Y., \& pour Nosrani, S. E. (2020). The Evaluation of Differences on Geriatric Syndromes between Active and Sedentary Elderly. Journal of Sports Science, 8, 56-66.

44. Kushkestani, M., Parvani, M., Ebrahimpour Nosrani, S., \& Bathaeezadeh, S. Y. (2020). The Relationship between Body Composition with Blood Pressure and Sleep Quality in Male Dormitory Student at Allameh Tabataba'i University. New Approaches in Sport Sciences, 1(2), 77-92.

45. Kushkestani, M., Parvani, M., \& maria Teixeira, A. (2020). Physical Activity is a Preventive Factor Against SARSCOV-2 in Healthy Subjects (Possible Cellular and Molecular Mechanisms). Biomedical Journal of Scientific \& Technical Research, 29(3), 22429-22436.

46. Kushkestani, M., Parvani, M., Moradi, K., \& Moghadassi, M. (2020). Malnutrition is Associated with Cognitive Function, Tiredness and Sleep Quality in Elderly Living Nursing Hom. Journal of Aging Science, 8(3).

47. Kushkestani, M., Parvani, M., Nosrani, S. E. P., \& Rezaei, S. (2020a). The Relationship between Anthropometric Indices and Lipid Profiles In-OfficeEmployees. Journal of Sports Science, 8, 76-82.

48. Kushkestani, M., Parvani, M., Nosrani, S. E., \& Rezaei, S. (2020b). The Physical Activity and Fall Risk Among Iranian Older Male Adults. The Open Nursing Journal, 14(1). 
49. Kushkestani, M., Parvani, M., Nosrani, S. E., Rezaei, S., \& Karimi, M. (2020). Lipid Profile and Hepatic Enzymes Differences between Pre-diabetes and Normal Staff. Journal of Sports Science, 8, 67-75.

50. Kushkestani, M., Parvani, M., \& Rezaei, S. (2020). Investigating the cognitive function of the elderly and related factors in nursing homes in Tehran in 2019. Journal of Gerontology, 4(4), $0-0$.

51. Kuspinar, A., Verschoor, C. P., Beauchamp, M. K., Dushoff, J., Ma, J., Amster, E., Bassim, C., Dal Bello-Haas, V., Gregory, M. A., \& Harris, J. E. (2020). Modifiable factors related to life-space mobility in community-dwelling older adults: Results from the Canadian Longitudinal Study on Aging. BMC Geriatrics, 20(1), 35.

52. Kwon, Y. N., \& Yoon, S. S. (2017). Sarcopenia: Neurological point of view. Journal of Bone Metabolism, 24(2), 83-89.

53. Lee, P. G., \& Halter, J. B. (2017). The pathophysiology of hyperglycemia in older adults: Clinical considerations. Diabetes Care, 40(4), 444-452.

54. Lelbach, A., \& Koller, A. (2017). Mechanisms underlying exercise-induced modulation of hypertension. Journal of Hypertension Research, 3(2), 35-44.

55. Liang, J., Zeng, Z., Zhang, Y., \& Chen, N. (2020). Regulatory role of exercise-induced autophagy for sarcopenia. Experimental Gerontology, 130, 110789.

56. Libby, P., \& Kobold, S. (2019). Inflammation: A common contributor to cancer, aging, and cardiovascular diseases-expanding the concept of cardio-oncology. Cardiovascular Research, 115(5), 824-829.

57. Liberman, K., Forti, L. N., Beyer, I., \& Bautmans, I. (2017). The effects of exercise on muscle strength, body composition, physical functioning and the inflammatory profile of older adults: A systematic review. Current Opinion in Clinical Nutrition and Metabolic Care, 20(1), 30-53.

58. Lichtenberg, T., von Stengel, S., Sieber, C., \& Kemmler, W. (2019). The favorable effects of a high-intensity resistance training on sarcopenia in older community-dwelling men with osteosarcopenia: The randomized controlled FrOST study. Clinical Interventions in Aging, $14,2173$.

59. Liguori, I., Russo, G., Curcio, F., Bulli, G., Aran, L., Della-Morte, D., Gargiulo, G., Testa, G., Cacciatore, F., \& Bonaduce, D. (2018). Oxidative stress, aging, and diseases. Clinical Interventions in Aging, 13, 757. 
60. Liu-Ambrose, T., Davis, J. C., Best, J. R., Dian, L., Madden, K., Cook, W., Hsu, C. L., \& Khan, K. M. (2019). Effect of a home-based exercise program on subsequent falls among community-dwelling high-risk older adults after a fall: A randomized clinical trial. Jama, 321(21), 2092-2100.

61. Loeser, R. F. (2017). The role of aging in the development of osteoarthritis. Transactions of the American Clinical and Climatological Association, 128, 44.

62. MacDonald, H. V., Johnson, B. T., Huedo-Medina, T. B., Livingston, J., Forsyth, K. C., Kraemer, W. J., Farinatti, P. T., \& Pescatello, L. S. (2016). Dynamic resistance training as stand-alone antihypertensive lifestyle therapy: A meta-analysis. Journal of the American Heart Association, 5(10), e003231.

63. Magnuson, A., Sattar, S., Nightingale, G., Saracino, R., Skonecki, E., \& Trevino, K. M. (2019). A practical guide to geriatric syndromes in older adults with cancer: A focus on falls, cognition, polypharmacy, and depression. American Society of Clinical Oncology Educational Book, 39, e96-e109.

64. McGurran, H., Glenn, J. M., Madero, E. N., \& Bott, N. T. (2019). Prevention and Treatment of Alzheimer's Disease: Biological Mechanisms of Exercise. Journal of Alzheimer's Disease, 69(2), 311-338.

65. McPhee, J. S., French, D. P., Jackson, D., Nazroo, J., Pendleton, N., \& Degens, H. (2016). Physical activity in older age: Perspectives for healthy ageing and frailty. Biogerontology, 17(3), 567-580.

66. Moore, G., Durstine, J. L., Painter, P., \& Medicine, A. C. of S. (2016). Acsm's exercise management for persons with chronic diseases and disabilities, $4 E$. Human Kinetics.

67. Mortimer, J. A., \& Stern, Y. (2019). Physical exercise and activity may be important in reducing dementia risk at any age. AAN Enterprises.

68. Müllers, P., Taubert, M., \& Müller, N. G. (2019). Physical exercise as personalized medicine for dementia prevention? Frontiers in Physiology, 10, 672.

69. Nascimento, C. M., Ingles, M., Salvador-Pascual, A., Cominetti, M. R., Gomez-Cabrera, M. C., \& Viña, J. (2019). Sarcopenia, frailty and their prevention by exercise. Free Radical Biology and Medicine, 132, 42-49.

70. Nations, U. (2017). World Population Ageing 2017: Highlights. New York: Department of Economic and Social Affairs, United Nations. 
71. Norman, J. E., Rutkowsky, J., Bodine, S., \& Rutledge, J. C. (2018). The potential mechanisms of exercise-induced cognitive protection: A literature review. Current Pharmaceutical Design, 24(17), 1827.

72. Otsuki, T., Namatame, H., Yoshikawa, T., \& Zempo-Miyaki, A. (2020). Combined aerobic and low-intensity resistance exercise training increases basal nitric oxide production and decreases arterial stiffness in healthy older adults. Journal of Clinical Biochemistry and Nutrition, 66(1), 62-66.

73. Pahor, M. (2019). Falls in older adults: Prevention, mortality, and costs. Jama, 321(21), 2080-2081.

74. Paley, C. A., \& Johnson, M. I. (2018). Abdominal obesity and metabolic syndrome: Exercise as medicine? BMC Sports Science, Medicine and Rehabilitation, 10(1), 1-8.

75. Pandey, A., Kitzman, D. W., Brubaker, P., Haykowsky, M. J., Morgan, T., Becton, J. T., \& Berry, J. D. (2017). Response to endurance exercise training in older adults with heart failure with preserved or reduced ejection fraction. Journal of the American Geriatrics Society, 65(8), 1698-1704.

76. Papa, E. V., Dong, X., \& Hassan, M. (2017). Resistance training for activity limitations in older adults with skeletal muscle function deficits: A systematic review. Clinical Interventions in Aging, 12, 955.

77. Parry, H. A., Roberts, M. D., \& Kavazis, A. N. (2020). Human Skeletal Muscle Mitochondrial Adaptations Following Resistance Exercise Training. International Journal of Sports Medicine, 41(06), 349-359.

78. Pescatello, L. S., MacDonald, H. V., Lamberti, L., \& Johnson, B. T. (2015). Exercise for hypertension: A prescription update integrating existing recommendations with emerging research. Current Hypertension Reports, 17(11), 87.

79. Picca, A., Calvani, R., Leeuwenburgh, C., Coelho-Junior, H. J., Bernabei, R., Landi, F., \& Marzetti, E. (2019). Targeting mitochondrial quality control for treating sarcopenia: Lessons from physical exercise. Expert Opinion on Therapeutic Targets, 23(2), 153-160.

80. Poblete-Aro, C., Russell-Guzman, J., Parra, P., Soto-Munoz, M., Villegas-Gonzalez, B., Cofre-Bolados, C., \& Herrera-Valenzuela, T. (2018). Exercise and oxidative stress in type 2 diabetes mellitus. Revista Medica de Chile, 146(3), 362-372.

81. Recchioni, R., Marcheselli, F., Antonicelli, R., Mensà, E., Lazzarini, R., Procopio, A. D., \& Olivieri, F. (2017). Epigenetic effects of physical activity in elderly patients with cardiovascular disease. Experimental Gerontology, 100, 17-27. 
82. Roh, J., Rhee, J., Chaudhari, V., \& Rosenzweig, A. (2016). The role of exercise in cardiac aging: From physiology to molecular mechanisms. Circulation Research, 118(2), 279-295.

83. Roth, G. A., Johnson, C., Abajobir, A., Abd-Allah, F., Abera, S. F., Abyu, G., Ahmed, M., Aksut, B., Alam, T., \& Alam, K. (2017). Global, regional, and national burden of cardiovascular diseases for 10 causes, 1990 to 2015. Journal of the American College of Cardiology, 70(1), 1-25.

84. Rutten, J. L. (2017). Prevention is better than cure: Can exercise prevent dementia. Maastricht Student Journal of Psychology \& Neuroscience, 6(1), 1-12.

85. Sabbahi, A., Arena, R., Elokda, A., \& Phillips, S. A. (2016). Exercise and hypertension: Uncovering the mechanisms of vascular control. Progress in Cardiovascular Diseases, 59(3), 226-234.

86. Seo, D. Y., Lee, S. R., Kim, N., Ko, K. S., Rhee, B. D., \& Han, J. (2016). Age-related changes in skeletal muscle mitochondria: The role of exercise. Integrative Medicine Research, 5(3), 182-186.

87. Sharman, J. E., Smart, N. A., Coombes, J. S., \& Stowasser, M. (2019). Exercise and sport science australia position stand update on exercise and hypertension. Journal of Human Hypertension, 1-7.

88. Sherrington, C., Michaleff, Z. A., Fairhall, N., Paul, S. S., Tiedemann, A., Whitney, J., Cumming, R. G., Herbert, R. D., Close, J. C., \& Lord, S. R. (2017). Exercise to prevent falls in older adults: An updated systematic review and meta-analysis. British Journal of Sports Medicine, 51(24), 1750-1758.

89. Skinner, S. N., Ellis, M. P., \& Pa, J. (2018). The effects of physical activity on cognition, dementia risk, and brain health. In APA handbook of dementia. (pp. 381-398). American Psychological Association.

90. Smith, G. E. (2016). Healthy cognitive aging and dementia prevention. American Psychologist, 71(4), 268.

91. Snijders, T., \& Parise, G. (2017). Role of muscle stem cells in sarcopenia. Current Opinion in Clinical Nutrition \& Metabolic Care, 20(3), 186-190.

92. Sun, Z. (2015). Aging, arterial stiffness, and hypertension. Hypertension, 65(2), 252-256.

93. Tang, O., Matsushita, K., Coresh, J., Sharrett, A. R., McEvoy, J. W., Windham, B. G., Ballantyne, C. M., \& Selvin, E. (2020). Mortality implications of prediabetes and diabetes in older adults. Diabetes Care, 43(2), 382-388. 
94. Tartibian, B., Kushkestani, M., Ebrahimpour Nosrani, S., \& Parvani, M. (2019). Relationship between the Level of Physical Activity and Nutritional Status with Fatigue in Elderly Residents of Rest Homes in Tehran. New Approaches in Sport Sciences, 1(2), 155-168.

95. Tsukiyama, Y., Ito, T., Nagaoka, K., Eguchi, E., \& Ogino, K. (2017). Effects of exercise training on nitric oxide, blood pressure, and antioxidant enzymes. Journal of Clinical Biochemistry and Nutrition, 16-108.

96. Tzemos, N., Lim, P. O., Mackenzie, I. S., \& MacDonald, T. M. (2015). Exaggerated exercise blood pressure response and future cardiovascular disease. The Journal of Clinical Hypertension, 17(11), 837-844.

97. Umpierre, D., Santos, L. P., Botton, C. E., Wilhelm, E. N., Helal, L., Schaun, G. Z., Ferreira, G. D., De Nardi, A. T., Pfeifer, L. O., \& da Silveira, A. D. (2019). The "Hypertension Approaches in the Elderly: A Lifestyle study" multicenter, randomized trial (HAEL Study): rationale and methodological protocol. BMC Public Health, 19(1), 1-13.

98. Villafañe, J. H. (2018). Exercise and osteoarthritis: An update. Journal of Exercise Rehabilitation, 14(4), 538.

99. Vitale, G., Cesari, M., \& Mari, D. (2016). Aging of the endocrine system and its potential impact on sarcopenia. European Journal of Internal Medicine, 35, 10-15.

100. Wang, H.-X., MacDonald, S. W., Dekhtyar, S., \& Fratiglioni, L. (2017). Association of lifelong exposure to cognitive reserve-enhancing factors with dementia risk: A communitybased cohort study. PLoS Medicine, 14(3), e1002251.

101. WHO. (2018). The top 10 causes of death. https://www.who.int/news-room/factsheets/detail/the-top-10-causes-of-death

102. WHO. (2020). Dementia. https://www.who.int/news-room/fact-sheets/detail/dementia

103. Wu, S., Jin, C., Li, S., Zheng, X., Zhang, X., Cui, L., \& Gao, X. (2019). Aging, arterial stiffness, and blood pressure association in Chinese adults. Hypertension, 73(4), 893899.

104. Wu, Y., Panza, G. A., Taylor, B. A., \& Pescatello, L. S. (2019). Healthy Aging and Exercise: Treating Disease and Disability. In Healthy Aging (pp. 241-261). Springer.

105. Xu, F., Cohen, S. A., Lofgren, I. E., Greene, G. W., Delmonico, M. J., \& Greaney, M. L. (2019). The Association between physical activity and metabolic syndrome in older adults with obesity. The Journal of Frailty \& Aging, 8(1), 27-32. 
106. Yaribeygi, H., Atkin, S. L., Simental-Mendía, L. E., \& Sahebkar, A. (2019). Molecular mechanisms by which aerobic exercise induces insulin sensitivity. Journal of Cellular Physiology, 234(8), 12385-12392.

107. Yoo, S.-Z., No, M.-H., Heo, J.-W., Park, D.-H., Kang, J.-H., Kim, S. H., \& Kwak, H.B. (2018). Role of exercise in age-related sarcopenia. Journal of Exercise Rehabilitation, 14(4), 551.

108. Zampogna, B., Papalia, R., Papalia, G. F., Campi, S., Vasta, S., Vorini, F., Fossati, C.,

Torre, G., \& Denaro, V. (2020). The role of physical activity as conservative treatment for hip and knee osteoarthritis in older people: A systematic review and meta-analysis. Journal of Clinical Medicine, 9(4), 1167.

109. Zhang, D., Liu, X., Liu, Y., Sun, X., Wang, B., Ren, Y., Zhao, Y., Zhou, J., Han, C., \& Yin, L. (2017). Leisure-time physical activity and incident metabolic syndrome: A systematic review and dose-response meta-analysis of cohort studies. Metabolism, 75, 36-44.

110. Zheng, G., Xia, R., Zhou, W., Tao, J., \& Chen, L. (2016). Aerobic exercise ameliorates cognitive function in older adults with mild cognitive impairment: A systematic review and meta-analysis of randomised controlled trials. British Journal of Sports Medicine, 50(23), 1443-1450.

111. Zhou, H., Peng, K., Tiedemann, A., Peng, J., \& Sherrington, C. (2019). Risk factors for falls among older community dwellers in Shenzhen, China. Injury Prevention, 25(1), 3135.

\section{AUTHOR CONTRIBUTIONS}

M.K and M.P were involved in the conception and wrote the manuscript. M.K was involved in the manuscript editing, manuscript review, and final revision. M.P was involved in the preparation and draft of the manuscript. M.G and Z.A were involved in the preparation of the manuscript.

\section{CONFLICTS OF INTEREST}

The authors declare no conflict of interest.

\section{FUNDING}

This research received no external funding.

\section{COPYRIGHT}

(C) Copyright 2022: Publication Service of the University of Murcia, Murcia, Spain. 